\title{
Scanning Electron Microscopy of Lagochilascaris minor Leiper, 1909 (Nematoda: Ascarididae)
}

\author{
Reinalda Marisa Lanfredi/ ${ }^{+}$, Habib Fraiha Neto ${ }^{*}$, Delir Corrêa Gomes ${ }^{* *}$
}

Laboratório de Helmintologia, Programa de Biologia Celular e Parasitologia, Instituto de Biofísica Carlos Chagas Filho, CCS, Bloco G, UFRJ, Cidade Universitária, 21949-900 Rio de Janeiro, RJ, Brasil *Instituto Evandro Chagas, Av. Almirante Barroso 492, 66090-000 Belém, PA, Brasil ** Laboratório de Helmintos Parasitos de Vertebrados, Departamento de Helmintologia, Instituto Oswaldo Cruz, Av. Brasil 4365, 21045-900 Rio de Janeiro, RJ, Brasil

Lagochilascaris minor Leiper, 1909 is a parasitic nematode with its biological cycle still unknown, even though it was found in humans, domestic and silvatic animals. Adult worms, collected by surgical drainage from a human patient from the State of Pará, Brazil, were micrographed using a scanning electron microscope. Morphological aspects of males and females such as cephalic structures, caudal papillae and cuticular patterns were analyzed and compared with the previous descriptions adding new data for the identification of this species.

Key words: Lagochilascaris minor - Nematoda - morphology - scanning electron microscopy

Since 1909, when Leiper first described Lagochilascaris minor, this nematode has been found parasitizing humans, domestic cats (Fraiha Neto et al. 1989), dogs (Sturion et al. 1982) and silvatic carnivores (Brenes-Madrigal et al. 1972, Volcan \& Medrano 1991). This parasite has neotropical distribution, with 68 human cases reported in Central and South America, most of them in the Amazon Region (Fraiha Neto et al. 1989, Ootsburg 1992, Veloso et al. 1992, Nascimento et al. 1993, Bento et al. 1993). The parasitism of $L$. minor in domestic animals seems to be accidental, as in humans, since the pathogeny is similar.

Lagochilascaris minor life cycle is not clear yet, since adult worms, as well as larval stages and eggs are found associated in lesions of humans and animals. Its mode of transmission is also unknown. Sprent (1971) proposed the ingestion of eggs and the larval pulmonary migratory cycle for humans. Since eggs can hatch in water, Fraiha Neto et al. (1989) proposed ingestion of larvae and their immediate penetration in the tissues, starting the cervical lesions. Volcan et al. (1992) obtained the experimental heteroxenous cycle in white mice, acting as intermediate hosts and cats as final hosts. Campos et al. (1989) also obtained the heteroxenous life cycle with mice and cats as experimental mod-

\footnotetext{
+Corresponding author: Fax: +55-21-280.8193. Email: reylanf@ibccf.biof.ufrj.br. CNPq fellow Proc. 521431/ 95-6

***CNPq fellow Proc. 303124/89-0

Received 19 September 1997

Accepted 4 March 1998
}

els; they also observed that the parasite did not develop when infective eggs were inoculated per os in cats and that infected cats presented eggs in all developmental stages and third stage larvae in the tissue lesions (lungs and cervical region).

Although the epidemiology, the biology and the morphology of the Lagochilascaris species are well described by Sprent (1971), there are still some difficulties to achieve the specific differentiation and several authors report to these worms only referring to their genus (Brenes-Madrigal et al. 1972, Moraes et al. 1985, Volcan \& Medrano 1991). This study presents additional morphological aspects of L. minor collected in Brazil, observed by scanning electron microscopy (SEM) that clarifies and confirms features of the cephalic structures and male caudal papillae used as taxonomic characters.

\section{MATERIALS AND METHODS}

Twenty-five worms were collected from a patient from State of Pará, Brazil, by surgical drainage in an intramastoid and cranial abscess. They were fixed in formaldehyde 5\% and cleared in lactophenol and identified under a light microscope according to Sprent (1971). For SEM, adult worms were washed once with buffer (PBS), post fixed in osmium tetroxide $1 \%$ in cacodilate buffer, washed with the same buffer, dehydrated in increasing ethanol series and critical point dried, covered with gold and electronmicrographed using a JSM Jeol $25 \mathrm{~S}$ II and Zeiss 962 equipment, at $15 \mathrm{kV}$ voltage acceleration.

\section{RESULTS}

Adult specimens, identified by light microscopy as Lagochilascaris minor Leiper, 1909, studied 
herein are stout and have tapered extremities; the males are smaller than the females, but the anterior end is similar in shape in both sexes. The anterior end is dome shaped, formed by three wider than long lips, that are separated from the rest of the body by a deep groove (Figs 1, 3). The posterior margin of the groove forms three triangular interlabial projections (Figs 1, 2, 3). Each lip presents a deep anterior fold, forming a longitudinal inner groove (Figs 1, 3). The posterior margin of the lips is round with a concavity on each side (Fig. 3 ). The three lips are concentrically located around the oral opening (Fig. 1).

The dorsal lip harbors two sub-dorsal papillae, the two subventral lips have one ventrolateral papilla and one small lateral papilla and one amphid placed side by side (Figs 1, 3)

The excretory pore is located at a short distance from the anterior end (Fig. 2); at this place there is an interruption of the cuticular striations (Fig. 4). The lateral lines are well defined just behind the excretory pore level (Fig. 2).

The vulvar opening is located near the middle of female body, the inner cuticle becomes finely striated (Fig. 5). The female tail is straight, the anus opens near the posterior end (Fig. 6). The phasmids are seen at the end of the lateral line, a short distance from the pointed or rounded tail tip; at this place the cuticular striations are modified (Figs $6,7)$. The egg shell presents excavations of variable diameters in its surface (Fig. 5).

The male posterior region is ventrally curved

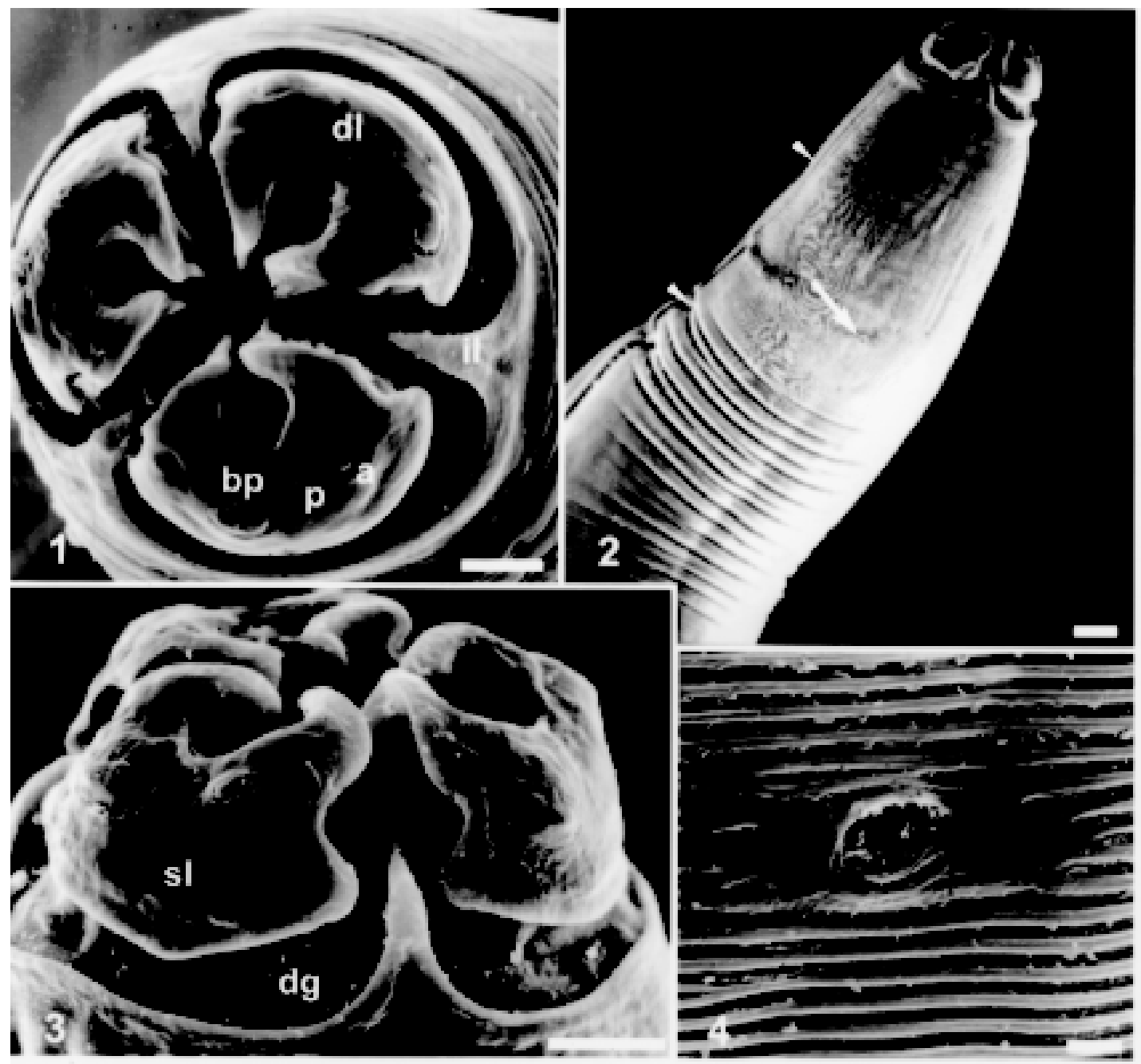

Lagochilascaris minor - Fig. 1: anterior end in face view. Dorsal lip (dl) harboring two sub-dorsal papillae (bp) and subventral lips with one ventrolateral papilla (bp), one small papilla (p) and one amphid (a), triangular interlabial prolongations (il). Bar $=25 \mu \mathrm{m}$. Fig. 2: longitudinal ventral view of the anterior region, excretory pore (arrow) and lateral line (arrow heads). Bar $=50 \mu \mathrm{m}$. Fig. 3 : lateral view of the lips showing in detail the lips contour, the deep groove (dg) around the lips forming the interlabial projection, one subventral lip (sl) with one big papilla, one small papilla and one amphid. Bar $=25 \mu \mathrm{m}$. Fig. 4: detail of the excretory pore and body cuticular striations. Bar $=5 \mu \mathrm{m}$. 


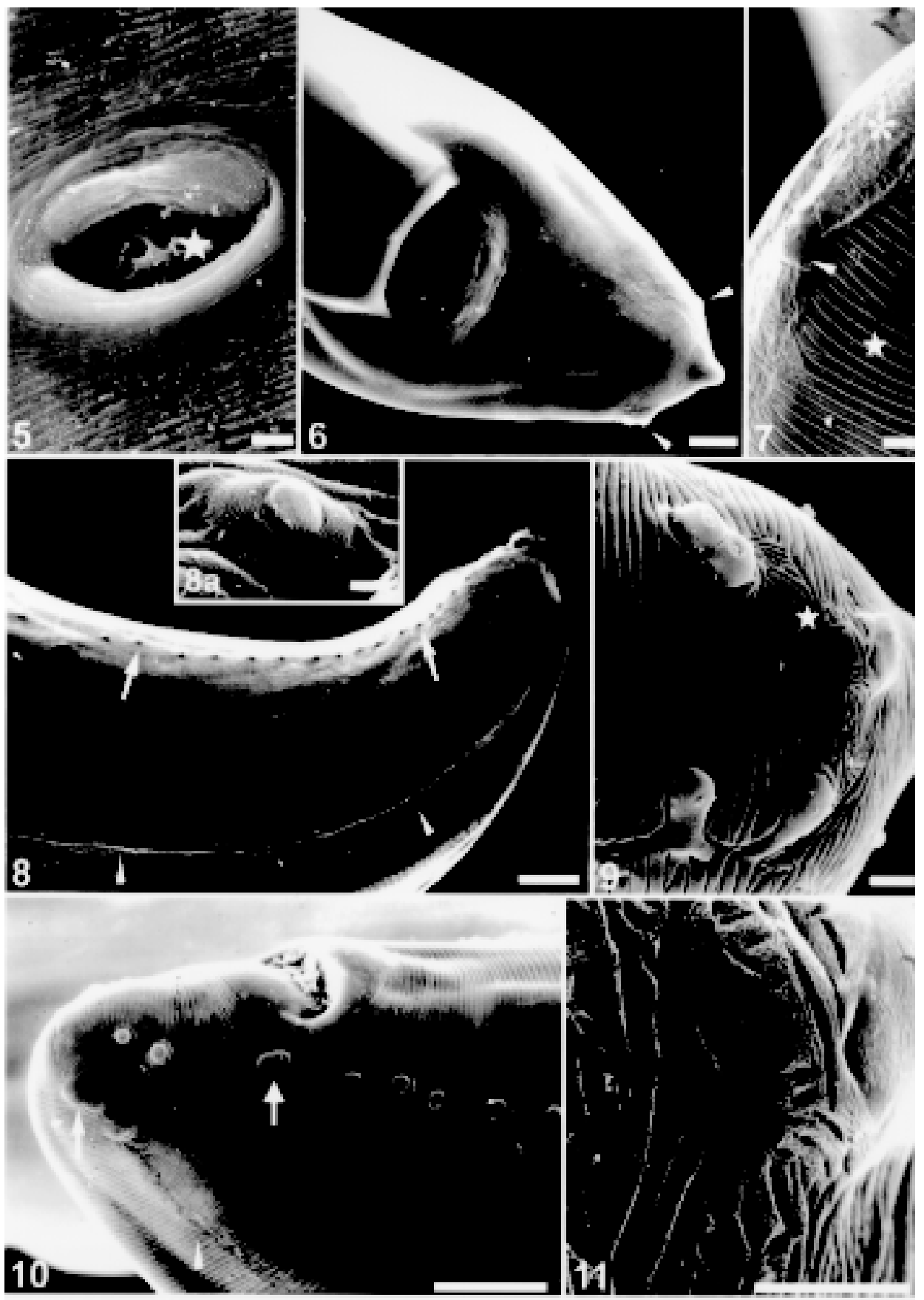

Lagochilascaris minor - Fig. 5: vulva with an egg (star) in the vagina. Bar $=10 \mu \mathrm{m}$. Fig. 6: posterior region showing the anal opening and one phasmid on each side of the tail (arrow heads). Bar $=25 \mu \mathrm{m}$. Fig. 7: detail of the posterior end presenting one phasmid (arrow head), the cuticular striations (star) and the decorated cuticular pattern at the amphid level (asterisk). Bar $=5 \mu \mathrm{m}$. Fig. 8: lateroventral view of the posterior region showing the lateral line (arrow heads) and the precloacal papilla (small arrows). Bar $=50 \mu \mathrm{m}$. Fig. $8 \mathrm{a}$ : detail of the single median precloacal papilla. Bar $=2.5 \mu \mathrm{m}$. Fig. 9: detail of the posterior end showing the double papillae, one papilla and one phasmid. Notice the cuticular striations and decorated cuticular pattern at the phasmid level (star). Bar $=5 \mu \mathrm{m}$. Fig. 10: posterior end showing the cloacal aperture, adcloacal double papillae large (arrow), pre and postcloacal papillae, phasmid (arrow) and lateral line (arrow head). Bar $=50 \mu \mathrm{m}$. Fig. 11: detail of the decorated cuticular pattern with a porous surface. Bar $=5 \mu \mathrm{m}$. 
(Fig. 8). The 22-28 pairs of precloacal papillae are button-like, sessile, arranged in two lateroventral rows (Figs 8,10). A single and large papilla is located in a median ventral line, anteriorly to the cloacal opening (Fig. 8a) and a pair of double adcloacal papillae is also observed (Fig. 10). At the end of the lateral line, the cuticular striations are modified, presenting a decorated porous pattern (Figs 9,10 ); around this area there are two pairs of single ventrolateral papillae, one pair of double lateral papillae plus one phasmid fused to another papilla (Figs 9, 11).

\section{Taxonomic summary}

Host: Homo sapiens L.

Site of infection: intramastoid and cranial abscess. Locality: State of Pará, Brazil.

Deposited material: Instituto Oswaldo Cruz Helminthological Collection (CHIOC) No. 33597 (wet material).

\section{REMARKS}

The SEM of the L. minor anterior end shows the morphology of the lips, cephalic papillae and amphids localization in accordance with the redescription by Sprent (1971) (Figs 1, 2,3). The lateral allae described by the previous author was not seen by us, but it was possible to recognize a conspicuous lateral line, specially at the anterior portion of the body (Figs 2, 8, 10). Males and females presented a cuticular decorated pattern at the posterior end at the phasmid level; this particular aspect of the cuticle, was not described before for L. minor.

Some females presented a round tail, as described by Sprent (1971), but some showed a pointed end (Fig. 6). The prominent phasmids were also seen at the end of the cuticular lateral line (Figs $6,7)$. One egg observed in the vagina presented in its surface sculptured pits as described by Sprent (1971) and Volcan et al. (1992) (Fig. 5).

The number, shape and distribution of caudal papillae in the male, observed by SEM, were slightly different from those described by Sprent (1971). He stated that there were up to 40 pairs of precloacal papillae; the first few from anterior end were lateral, followed by 8 pairs with conspicuous stalks and 20 or more sessile. In the same paragraph he adds: "the number of precloacal papillae is variable, in some specimens not more than 20 were observed". By SEM there were 22-28 pairs of precloacal papillae, all sessile; their localization was latero-ventral considering the lateral line (Figs $8,10)$. The median precloacal papilla was not double, as described by Sprent (1971), but a single and large papilla (Fig. 8a). Our observations also agree with this author, concerning the pair of double adcloacal papillae and the two pairs of subventral but, at the end of the lateral line, we observed two pairs of double lateral postcloacal papillae (Figs 9, 10 ); he stated that the phasmid was hardly seen and in our opinion was placed side by side to the papilla at the end of the region of decorated cuticular pattern near the tip of the tail (Figs 9, 11).

\section{ACKNOWLEDGMENTS}

To Drs Wanderley de Souza for the scanning electron microscope facilities and Roberto Magalhães Pinto for the valuable comments on the manuscript; to Genilton José Vieira and Marcos Gustavo Silva Ribeiro for their technical help with the micrographies; to students Andreia C de AT Mafra and Henrique Albuquerque for technical support. To the "Programa de Núcleos de Excelência (PRONEX)" for partial financial support.

\section{REFERENCES}

Brenes-Madrigal RR, Ruiz A, Frenkel JK 1972. Discovery of Lagochilascaris sp. in the larynx of a Costa Rica ocelot (Felis pardalis meamsi). J Parasitol 58: 978.

Bento RF, Mazza CC, Motti EF, Chan YT, Guimarães JR, Miniti A 1993. Human Lagochilascariasis treated successfully with ivermectin: a case report. Rev Inst Med Trop São Paulo 35: 373-375.

Campos DMB, Freire LG 1989. Considerações sobre a evolução de Lagochilascaris minor Leiper, 1909 II. Susceptibilidade de diferentes linhagens de camundongos e hamsters a ovos embrionados do parasito. Cong Soc Bras de Med Trop, Florianópolis, SC, p. 106.

Fraiha Neto H, Leão RNQ, Costa FSA 1989. Lagochilascariase humana e dos animais domésticos. Zoon Rev Int 1: 25-33.

Moraes MAP, Arnaud MVC, Macedo RC, Anglado AE 1985. Infecção pulmonar fatal por Lagochilascaris sp. provavelmente Lagochilascaris minor, Leiper 1909. Rev Inst Med Trop São Paulo 27: 46-52.

Nascimento JEA, Silva GM, Tadano T, Valadares Filho M, Akiyama AM, Castelo A 1993. Infection of the soft tissue of neck due to Lagochilascaris minor. Trans R Soc Trop Med Hyg 87: 198.

Oostburg BF 1992. The sixth case of lagochilascariasis minor in Surinam. Trop Geographical Med 44: 154159.

Sprent JFA 1971. Speciation and development in the genus Lagochilascaris. Parasitology 62: 71-112.

Sturion DJ, Gaste L, Yamamura MH 1982. Alterações esofágicas pelo Lagochilascaris minor em cão. Cong Bras de Med Vet, SC, p. 265.

Veloso MG, Faria MD, Freitas JD, Moraes MA, Gorini DF, Mendonça JL 1992. Human lagochilascariasis: 3 cases encountered in the Federal District, Brazil. Rev Inst Med Trop São Paulo 34: 587-591.

Volcan GS, Medrano CE 1991. Infection natural de Speothos venaticus (Carnivora: Canidae) por estadios adultos de Lagochilascaris sp. Rev Inst Med Trop São Paulo 33: 451-458.

Volcan GS, Medrano CE, Payares G 1992. Experimental heteroxenous cycle of Lagochilascaris Leiper, 1909 (Nematoda: Ascarididae) in white mice and cats. Mem Inst Oswaldo Cruz 87: 525-532. 